\title{
Faktor-Faktor Penyebab Ketidaklengkapan Pengisian Rekam Medis Rawat Inap di Rumah Sakit Universitas Muhammadiyah Malang
}

\section{Factors Affecting Incomplete Inpatient Medical Record Completion at Muhammadiyah University Hospital Malang}

\author{
Nurhaidah ${ }^{1}$, Tatong Harijanto ${ }^{2}$, Thontowi Djauhari ${ }^{3}$ \\ ${ }^{1}$ Akademi Kebidanan Harapan Bunda Bima Nusa Tenggara Barat \\ ${ }^{2}$ Program Studi Magister Manajemen Rumah Sakit Fakultas Kedokteran Universitas Brawijaya Malang \\ ${ }^{3}$ Rumah Sakit Universitas Muhammadiyah Malang
}

\begin{abstract}
ABSTRAK
Salah satu upaya untuk meningkatkan mutu sarana pelayanan kesehatan yaitu dengan meningkatkan mutu pelayanan rekam medis meliputi kelengkapan, kecepatan dan ketepatan dalam memberikan informasi untuk kebutuhan pelayanan kesehatan. Rekam medis yang lengkap dan akurat dapat digunakan sebagai referensi pelayanan kesehatan, dasar hukum (medico legal), menunjang informasi untuk meningkatkan kualitas medis, riset medis dan dijadikan dasar menilai kinerja rumah sakit. Tujuan penelitian ini mengidentifikasi faktor-faktor yang penyebab ketidaklengkapan pengisian rekam medis rawat inap di Rumah Sakit Universitas Muhammadiyah Malang (RS UMM). Metode analisis data yang digunakan adalah deskriptif. Teknik pengumpulan data dengan cara studi dokumen, wawancara dan observasi. Studi dokumen dilakukan pada 40 rekam medis rawat inap yang belum dilakukan assembling, sedangkan wawancara dilakukan kepada petugas terkait untuk mengetahui faktor-faktor penyebab ketidaklengkapan dokumen rekam medis. Observasi dilakukan untuk melengkapi data hasil wawancara. Hasil studi dokumen pada 40 dokumen rekam medis rawat inap didapatkan bahwa jumlah rekam medis yang tidak diisi lengkap adalah $100 \%$, dengan presentasi ketidaklengkapan yang paling banyak adalah dari dokter. Hasil wawancara dan observasi ditemukan tidak adanya kebijakan, panduan dan SPO pengisian rekam medis, kesadaran dokter untuk mengisi rekam medis kurang, tidak adanya data ketidaklengkapan rekam medis, sistem monitoring dan evaluasi rekam medis tidak efektif dan alur berkas rekam medis rawat inap yang tidak sesuai dengan standar. Sebagai solusi untuk meningkatkan kelengkapan pengisian rekam medis yaitu dengan membuat kebijakan, panduan dan SPO tentang pengisian rekam medis.
\end{abstract}

Kata Kunci: Ketidaklengkapan pengisian rekam medis

\begin{abstract}
One of the efforts to improve the quality of health care facilities is to improve the service quality of medical records including completeness, speed, and accuracy in providing information to health care needs. Complete and accurate medical records can be used as a healthcare reference, legal basis (medico legal), supporting information to improve medical information quality, medical research, and as the basis of assessing hospital performance. The objective of the study was to determine the factors that affect the incompleteness of inpatient medical record at Muhammadiyah University Hospital (UMM Hospital). Descriptive analysis was used to analyze the data, while data collection was done through interview, observation, and document study. The study has been conducted among 40 unassembled inpatient medical record documents, while interview was done to the relevant officers to determine the factors that cause the incompleteness of medical record documents. The observation was carried out to complete the interview section, whereas, the document study showed that the number of incomplete medical record was $100 \%$, that mostly performed by doctors. Both interview and observation found that there were absence of policies, guidelines and SOP on completing medical records, low awareness of physicians to fill medical records, the absence of medical record incompleteness data, monitoring and evaluation system of ineffective medical records, and unstandardized pathway of inpatient medical record file. As a solution to improve the completeness of the medical record, creating policies, guidelines, and SOP about completing the medical record are needed.
\end{abstract}

Keywords: Incomplete medical record

Korespondensi: Nurhaidah. Akademi Kebidanan Harapan Bunda Bima Nusa Tenggara Barat, Jl. Imam Bonjol No.56, Santi Barat Kota Bima Nusa Tenggara Barat Tel. (0374)647021 Email: bimanurhaidah@gmail.com 


\section{PENDAHULUAN}

setiap pelayanan kesehatan termasuk rumah sakit diwajibkan untuk menyelenggarakan rekam medis (1). Rekam medis diartikan sebagai keterangan yang tertulis maupun yang terekam yang berisi identitas, anamnesis, pemeriksaaan fisik, laboratorium, diagnosa serta segala pelayanan dan tindakan medis yang diberikan kepada pasien, dan pengobatan baik yang dirawat inap, rawat jalan maupun yang mendapatkan pelayanan gawat darurat. Tenaga yang bertugas mengisi rekam medis ialah dokter umum, dokter spesialis, dokter gigi dan dokter gigi spesialis, dokter tamu yang merawat pasien di rumah sakit, residen yang sedang melaksanakan praktek, tenaga paramedik perawat dan non perawat yang terlibat langsung dalam memberikan pelayanan kesehatan kepada pasien yaitu diantaranya perawat, perawat gigi, bidan, tenaga laboratorium klinik, gizi, anestesi, penata rontgent, rehabilitasi medis dan lainnya (2). Salah satu upaya untuk meningkatkan mutu sarana pelayanan kesehatan yaitu dengan meningkatkan mutu pelayanan rekam medis meliputi kelengkapan, kecepatan dan ketepatan dalam memberikan informasi untuk kebutuhan pelayanan kesehatan. Berdasarkan upaya tersebut maka mutu pelayanan rekam medis akan menggambarkan mutu pelayanan medis di sarana pelayanan kesehatan (3).

Rumah Sakit Universitas Muhammadiyah Malang (RS UMM) adalah rumah sakit umum swasta milik Universitas Muhammadiyah Malang. RS UMM mulai dibangun pada tahun 2009 dan diresmikan pada tanggal 17 Agustus 2013. Rumah sakit ini merupakan rumah sakit tipe $C$ dengan kapasitas 112 tempat tidur. Berdasarkan hasil studi pendahuluan dapat dilihat bahwa capaian standar pelayanan minimal di unit rekam medik Rumah Sakit Universitas Muhammadiyah Malang masih belum optimal. Hal ini disebabkan masih ada beberapa indikator yang belum tercapai yaitu: a.) Kelengkapan Pengisian rekam medis 24 jam setelah selesai pelayanan, b.) waktu penyediaan rekam medik pelayanan rawat jalan, c.) waktu penyediaan rekam medik pelayanan rawat inap, d.) kelengkapan informed consent setelah mendapatkan informasi yang jelas. Kelengkapan Pengisian rekam medis 24 Jam Setelah Selesai Pelayanan yang dicapai pada bulan April adalah sebesar 89\%, Mei 93\% dan pada bulan Juni sebesar $70 \%$ sedangkan untuk standar penilaiannya $100 \%$ berdasarkan KEPMENKES RI No.129/MENKES/SK/II/2008 tentang Standar Pelayanan Minimum (SPM) Rumah Sakit (3). Setelah ditelusuri lebih jauh, tidak didapatkan data sebagai dasar perhitungan pencapaian indikator kinerja rekam medis. Hal ini menunjukkan bahwa terjadi kesenjangan antara pelayanan yang ada di unit rekam medis dengan standar yang ada.

Menurut Depkes tahun 2006 rekam medis yang lengkap adalah dokumen rekam medis yang telah diisi lengkap oleh dokter dalam waktu $\leq 24$ jam setelah selesai pelayanan/ setelah pasien rawat inap diputuskan untuk pulang meliputi identitas pasien, anamnesis, rencana asuhan, pelaksanaan asuhan, tindak lanjut dan resume (4). Rekam medis yang lengkap, menyediakan informasiinformasi yang dapat digunakan untuk berbagai keperluan. Keperluan tersebut diantaranya adalah sebagai bahan pembuktian dalam perkara hukum, bahan penelitian dan pendidikan serta dapat digunakan sebagai alat untuk analisis dan evaluasi terhadap mutu pelayanan yang diberikan oleh rumah sakit (5).
Rekam medis di rumah sakit dibedakan menjadi dua yaitu rekam medis pasien rawat jalan dan rawat inap. Rekam medis rawat jalan bentuknya lebih sederhana dibandingkan dengan rekam medis rawat inap. Rekam medis rawat inap berupa berkas/dokumen yang terdiri dari berbagai formulir isian, tergantung kepentingan rumah sakit. Isi rekam medis untuk pasien rawat inap dan perawatan satu hari sekurang-kurangnya memuat: identitas pasien, tanggal dan waktu, hasil anamnesis, mencakup sekurang-kurangnya keluhan dan riwayat penyakit, hasil pemeriksaan fisik dan penunjang medik, diagnosa, rencana penatalaksanaan, pengobatan dan/atau tindakan, persetujuan tindakan jika diperlukan, catatan observasi klinis dan hasil pengobatan, ringkasan pulang (discharge summary), nama dan tanda tangan dokter, dokter gigi, atau tenaga kesehatan tertentu yang memberikan pelayanan kesehatan (6).

Penanggung jawab utama kelengkapan rekam medis adalah dokter sebagai penentu diagnosis dan petugas rekam medis sebagai pengkaji kelengkapannya. Kelengkapan rekam medis menurut UU Praktik Kedokteran Pasal 46 dan pasal 47 menjadi tanggung jawab dokter dan dokter gigi sebagai bagian standar pelayanan kesehatan (7). Undang-Undang Praktik Kedokteran (UUPK) No. 29 tahun 2004 paragraf 3 Pasal 46 menyatakan: setiap dokter atau dokter gigi dalam menjalankan praktik kedokteran, wajib membuat rekam medis. Rekam medis sebagaimana dimaksud pada ayat 1 harus segera dilengkapi setelah pasien menerima pelayanan kesehatan. Bila yang bersangkutan dengan sengaja tidak membuat rekam medis sebagaimana yang dimaksud dalam pasal 46 ayat (1), maka dokter/dokter gigi dapat dipidana kurungan 1 tahun atau denda Rp. 50.000.000,-(8).

Ketidaklengkapan dokumen rekam medis menjadi salah satu masalah karena rekam medis seringkali merupakan satu-satunya catatan yang dapat memberikan informasi terinci tentang apa yang sudah terjadi selama pasien dirawat di rumah sakit. Hal ini akan mengakibatkan dampak internal dan eksternal karena hasil pengolahan data menjadi dasar pembuatan laporan baik internal rumah sakit maupun bagi pihak eksternal. Laporan ini berkaitan dengan penyusunan berbagai perencanaan rumah sakit, pengambilan keputusan oleh pimpinan khususnya evaluasi pelayanan yang diberikan dan diharapakan hasilnya menjadi lebih baik. Selain itu ketidaklengkapan RM juga menyebabkan terhambatnya proses klaim asuransi oleh pihak ketiga yaitu BPJS karena penulisan diagnosa utama atau disertai dengan diagnosa sekunder/tambahan akan sangat berpengaruh dengan besaran klaim asuransi yang diajukan. Dampak lain dari ketidaklengkapan rekam medis adalah terhambatnya proses tertibnya administrasi, dimana karena dokumen rekam medis yang seharusnya sudah berada di ruang penyimpanan tapi masih dikembalikan lagi ke dokter penangungjawab untuk dilengkapi (9). Kualitas rekam medis sangat penting karena ikut menentukan mutu pelayanan yang ada di rumah sakit. Hal ini mengingat rekam medis merupakan salah satu standar yang harus dipenuhi oleh instansi atau rumah sakit untuk mendapatkan predikat akreditasi (10).

\section{METODE}

Penelitian ini dilakukan dengan metode deskriptif. Cara pengumpulan data yang digunakan adalah studi dokumen, wawancara dan observasi. Studi dokumen dilakukan pada 
tanggal 26 Oktober 2015, berkas rekam medis yang dianalis adalah berkas rekam medis pasien yang telah pulang yang diserahkan oleh unit rawat inap ke unit rekam medis sebelum dilakukan assembling atau proses pengecekkan kelengkapannya. Berkas rekam medis diambil secara acak sejumlah 40 dengan poin penilaian 0 jika berkas rekam medis di isi lengkap, nilai 1 jika tidak lengkap dan apabila tidak diisi diberi poin 2. Penilaian kelengkapan rekam medis berdasarkan pada Pedoman Penyelenggaraan dan Prosedur Rekam Medis Rumah Sakit di Indonesia yang dikeluarkan oleh Departemen Kesehatan RI tahun 2006. Selanjutnya metode wawancara dilakukan untuk mencari faktor-faktor penyebab ketidaklengkapan dokumen rekam medis dan solusi pemecahan masalah. Wawancara dilakukan pada tanggal 2 dan 3 Oktober 2105 kepada 13 orang petugas rumah sakit yang terdiri dari kepala unit rawat inap, kepala bidang pelayanan, kepala bidang penunjang, kepala unit rekam medis, petugas rekam medis, dokter. Metode observasi dilakukan untuk melengkapi sekaligus pembuktian hasil wawancara.

\section{HASIL}

Hasil analisis pada 40 berkas rekam medis didapatkan bahwa jumlah rekam medis yang tidak lengkap adalah $100 \%$, dengan presentasi ketidaklengkapan yang paling banyak pada tanggungjawab dokter yang meliputi: 1.) resume medis, 2.) rencana pelayanan, 3.) status present, 4.) persetujuan dan penolakan tindakan, dan 5.) catatan perkembangan pasien terintegrasi dengan tingkat kelengkapan terendah adalah lembar konsultasi dokter.

Tabel 3. Analisis kelengkapan pengisian rekam medis rawat inap RS UMM

\begin{tabular}{|c|c|c|c|}
\hline No & Keterangan & $\begin{array}{c}\text { Skor } \\
\operatorname{Max}(80)\end{array}$ & $\begin{array}{l}\text { Presentase } \\
\text { Kelengkapan }\end{array}$ \\
\hline 1 & Form Judul Rekam Medis & 80 & 100 \\
\hline 2 & Form Persetujuan Umum & 66 & 83 \\
\hline 3 & Status Present & 66 & 83 \\
\hline \multirow{3}{*}{4} & a. Lembar Transfer Informasi & 76 & 95 \\
\hline & b. Penilaian Risiko Jatuh & 62 & 78 \\
\hline & c. Penilaian Tingkat Nyeri & 54 & 68 \\
\hline 5 & Rencana Pelayanan & 48 & 60 \\
\hline 6 & Persetujuan \& Penolakan Tindakan & 27 & 34 \\
\hline 7 & Cacatan Perkembangan Pasien Terintegrasi & 44 & 55 \\
\hline 8 & Konsultasi Dokter & 4 & 5 \\
\hline 9 & Penggunaan Obat pasien & 43 & 54 \\
\hline 10 & grafik Tanda Vital & 69 & 86 \\
\hline 11 & Pengkajian Medikal Bedah & 60 & 75 \\
\hline 12 & Catatan Kegiatan Harian Perawat & 66 & 83 \\
\hline \multirow{5}{*}{13} & a. Phlebitis Scale & 40 & 50 \\
\hline & b. Infeksi saluran Kemih (ISK) & \multicolumn{2}{|c|}{ Tidak Berlaku } \\
\hline & c. Infeksi Luka Operasi (ILO) & \multicolumn{2}{|c|}{ Tidak Berlaku } \\
\hline & d. Decubitus Scale & \multirow{2}{*}{\multicolumn{2}{|c|}{$\begin{array}{l}\text { Tidak Berlaku } \\
\text { Tidak Berlaku }\end{array}$}} \\
\hline & e. Ventilator Assosiated Pneumonia (VAP) & & \\
\hline \multirow[t]{3}{*}{14} & a. Hasil Pemeriksaan Lab & 72 & 100 \\
\hline & b. Hasil Pemeriksaan Radiologi & 12 & 100 \\
\hline & c. Hasil ECG & 10 & 100 \\
\hline 15 & Tempelan Duplikasi Resep & 80 & 100 \\
\hline 16 & Resume Medik & 48 & 60 \\
\hline 17 & Cheklist pemberian informasi & 64 & 80 \\
\hline 18 & Catatan Edukasi Terintegr asi Pasien/ Keluarg & rga 50 & 63 \\
\hline 19 & Resume Keperawatn & 54 & 68 \\
\hline 20 & Formulir Gizi- Skrining Lanjut & 56 & 70 \\
\hline 21 & Rencana Pemulangan Pasien & 52 & 65 \\
\hline
\end{tabular}

Sumber: Data rekam medis bulan oktober tahun 2015
Ketidaklengkapan pengisian rekam medis disebabkan oleh beberapa faktor yaitu: 1) faktor petugas (man), 2) faktor kebijakan (machine), 3) faktor prosedural (method), 4) faktor alat (material), dan faktor dana (money). Faktor mendasar pada aspek man adalah kesadaran dan pemahaman disamping tidak adanya monitoring dan evaluasi. Lemahnya kebijakan, tidak adanya standar prosedur, alur dan dukungan dana berkontribusi pada ketidaklengkapan rekam medik di rumah sakit.

Tabel 4. Pencarian akar masalah menggunakan metode fishbone

\begin{tabular}{|c|c|}
\hline Faktor & Akar Masalah \\
\hline \multirow[t]{3}{*}{ Man/ Petugas } & $\begin{array}{l}\text { 1. Kesadaran dokter untuk mengisi rekam } \\
\text { medis kurang }\end{array}$ \\
\hline & $\begin{array}{l}\text { 2. Persepsi tentang kelengkapan rekam medis } \\
\text { antara petugas rekam medis dan perawat } \\
\text { berbeda }\end{array}$ \\
\hline & $\begin{array}{l}\text { 3. Tidak ada tim monitoring dan evaluasi } \\
\text { rekam medis }\end{array}$ \\
\hline \multirow[t]{2}{*}{ Machine/ Kebijakan } & $\begin{array}{l}\text { 4. Tidak ada kebijakan, panduan dan SPO } \\
\text { pengisian rekam medis }\end{array}$ \\
\hline & $\begin{array}{l}\text { 5. Tidak ada sistem reward and pusihment } \\
\text { bagi petugas terkait }\end{array}$ \\
\hline \multirow[t]{3}{*}{ Method/ Prosedural } & $\begin{array}{l}\text { 6. Monitoring dan evaluasi terhadap } \\
\text { ketidaklengkapan dokumen rekam medis } \\
\text { kurang efektif }\end{array}$ \\
\hline & $\begin{array}{l}\text { 7. Sistem pencatatan oleh petugas rekam } \\
\text { medis belum berjalan baik }\end{array}$ \\
\hline & $\begin{array}{l}\text { 8. Alur berkas rekam medis tidak sesuai } \\
\text { standar }\end{array}$ \\
\hline \multirow[t]{2}{*}{ Material/ Alat } & $\begin{array}{l}\text { 9. Tidak ada data tentang ketidaklengkapan } \\
\text { pengisian rekam medis }\end{array}$ \\
\hline & $\begin{array}{l}\text { 10. Tidak ada cheklist penilaian kelengkapan } \\
\text { rekam medis }\end{array}$ \\
\hline Money/ Dana & $\begin{array}{l}\text { 11. Sumber dana terbatas untuk mendukung } \\
\text { kelengkapan }\end{array}$ \\
\hline
\end{tabular}

Berdasarkan hasil wawancara, salah satu penyebab ketidaklengkapan pengisian rekam medis adalah karena alur berkas rekam medis rawat inap di RS UMM tidak sesuai dengan standar pedoman penyelenggaraan rekam medis (RM) oleh Departemen Kesehatan RI. Setelah dilakukan obervasi alur berkas RM rawat inap memang belum sesuai dengan standar yang ada karena berkas RM pasien yang sudah pulang seharusnya dari unit rawat inap langsung dikembalikan ke unit rekam medis paling lambat 24 jam setelah pasien pulang melalui proses assembling, coding, indeks, filing, akan tetapi berkas RM tersebut oleh rumah sakit dibagi menjadi 2 yakni berkas RM pasien umum dan BPJS. Untuk RM pasien umum oleh unit rawat inap langsung dikembalikan ke unit rekam medis sedangkan RM pasien BPJS akan dibawa ke tim BPJS untuk dilakukan audit dan coding. Berkas RM yang masuk ke tim BPJS tersebut akan dikembalikan dalam tempo 1 bulan terhitung mulai tanggal penerimaan berkas RM. Hal ini menghambat proses assembling, coding, indeks, dan filing oleh petugas rekam medis (Lampiran 1 dan Lampiran 2).

Dari beberapa faktor yang menyebabkan ketidaklengkapan pengisian rekam medis rawat inap dilakukan penilaian dengan metode Urgency, Seriousness, Growth (USG) untuk menentukan prioritas masalah. Hasil analisis USG, faktor yang menjadi prioritas utama yang 
mempengaruhi ketidaklengkapan pengisian rekam medis rawat inap di Rumah Sakit Universitas Muhammadiyah Malang adalah tidak adanya kebijakan, panduan dan standar prosedur operasional pengisian rekam medis.

\section{DISKUSI}

Kelengkapan dokumen rekam medis merupakan hal yang sangat penting karena berpengaruh terhadap proses pelayanan yang dilakukan oleh petugas medis dan mempengaruhi kualitas dari pelayanan suatu rumah sakit (12). Hasil studi dokumen pada 40 berkas rekam medis didapatkan bahwa jumlah rekam medis yang tidak lengkap adalah $100 \%$, dengan presentasi ketidaklengkapan yang paling banyak adalah dari dokter.

Faktor yang menjadi penyebab utama ketidaklengkapan pengisian rekam medis rawat inap adalah karena tidak adanya kebijakan, panduan dan SPO pengisian rekam medis di unit rekam medis RS UMM. Hal ini mengakibatkan tidak adanya acuan bagi petugas terkait dalam melakukan pengisian rekam medis sehingga menimbulkan perbedaan persepsi tentang kelengkapan rekam medis. Kebijakan, pedoman/panduan, dan prosedur merupakan kelompok dokumen sebagai acuan untuk melaksanakan kegiatan, dimana kebijakan merupakan regulasi yang tertinggi di rumah sakit. Hal ini sejalan dengan hasil penelitian Rohman yang mengatakan bahwa adanya kebijakan manajemen rekam medis yang mendukung pengisian diagnosis dan keakuratan kode diagnosis sangat berpengaruh terhadap jalannya pengisian diagnosis dan keakuratan kode diagnosis yaitu antara kepala rekam medis, dokter dan petugas koding (13).

Penyebab lain dari ketidaklengkapan pengisian rekam medis adalah dari segi sumber daya manusia yakni dokter dan perawat yang kurang disiplin dalam melakukan pengisian rekam medis. Sebagian besar dokter yang ada di RS UMM merupakan dokter tamu sehingga dokter hanya memiliki waktu yang sedikit di rumah sakit. Sebuah studi mengatakan bahwa faktor-faktor penyebab ketidaklengkapan pengisian rekam medis adalah ketidakdisiplinan dan kurangnya kesadaran dokter akan pentingnya kelengkapan berkas rekam medis dan keterbatasan waktu dokter dalam melakukan pengisian rekam medis disebabkan beban kerja dokter yang tinggi (14). Hal ini didukung oleh hasil penelitian lain yang mengatakan bahwa ketidaklengkapan berkas rekam medis diakibatkan tenaga kesehatan yang kurang disiplin dalam mengisi rekam medis (15) . Faktor-faktor yang menyebabkan seringnya diagnosis utama tidak terisi diantaranya adalah dokter sibuk, pasien yang banyak, dokter mementingkan pelayanan, pasien APS (atas permintaan sendiri) atau pasien belum BLPL (boleh pulang), beban kerja yang banyak (dituntut kerja cepat tetapi masih ditambah kerja yang lain), memakan waktu yang banyak, berkas rekam medis sudah terdistribusi ke bagian lain, malas, tidak disiplin karena tidak tahu manfaatnya (13).

\section{DAFTAR PUSTAKA}

1. Imbar RV, dan Kurniawan Y. Perancangan Sistem Informasi Pelayanan Medis Rawat Jalan Poliklinik Kebidanan dan Kandungan pada RSUD Kota Batam. Jurnal Sistem Informasi. 2015;7(1): 53-67.
Sistem monitoring dan evaluasi pengisian rekam medis juga mempengaruhi kelengkapan pengisian rekam medis. Sistem monitoring dan evaluasi pengisian rekam medis di unit rekam medis RS UMM belum berjalan baik dikarenakan belum terbentuknya tim monitoring dan evaluasi serta tidak adanya sistem pencatatan maupun pelaporan mengenai ketidaklengkapan rekam medis oleh petugas rekam medis sehingga tidak ada perbaikan dalam ketidaklengkapan pengisian rekam medis. Hal ini sesuai dengan penelitian Mawarni yang mengatakan penyebab ketidaklengkapan pengisian rekam medis di instalasi rawat inap Rumah Sakit Muhammadiyah Lamongan adalah tidak adanya pelaksanaan monitoring sehingga proses pengisian rekam medis dengan lengkap tidak bisa dikendalikan (3). Salah satu faktor yang mempengaruhi kelengkapan rekam medis adalah supervisi teknis. Melaksanakan supervisi secara tepat dan sesuai dengan periode yang ditetapkan. Supervisi dapat dilakukan secara menyeluruh tidak hanya kepada dokter melalui sub komite mutu, namun kepada perawat dapat berfungsi untuk mengingatkan dokter yang tidak melakukan kelengkapan pengisian rekam medis (16).

Selain itu, penyebab ketidaklengkapan pengisian rekam medis dipengaruhi oleh alur berkas rekam medis. Alur berkas rekam medis di RS UMM belum sesuai dengan standar prosedur penyelenggaraan rekam medis. Ketidaksesuaian alur berkas rekam medis dapat mengambat proses penilaian kelengkapan rekam medis oleh petugas rekam medis serta menghambat proses penyerahan rekam medis apabila pasien datang ke rumah sakit untuk melakukan perawatan kesehatan. Penelitian Wuryandari (2013) mengatakan bahwa hasil pengisian rekam medis di RSUD Balung yang masuk kategori jelek disebabkan pengaruh dari proses pengisian rekam medis pada semua jenis profesi serta pengetahuan prosedur rendah dan pengetahuan alur rekam medis yang rendah (17).

Perlu adanya kebijakan, panduan dan SPO tentang pengisian rekam medis sebagai acuan bagi tenaga medis dan paramedis dalam melakukan pengisian rekam medis sebagai upaya untuk meningkatkan kelengkapan pengisian berkas rekam medis. Upaya lain adalah perlu adanya peningkatan kesadaran bagi dokter dan perawat maupun petugas terkait dalam melakukan pengisian rekam medis dengan diadakannya seminar legal aspek rekam medis dan memberlakukan sistem reward and punishment jika diperlukan sebagai motivasi dalam melakukan pengisian rekam medis. Selain itu, solusi untuk menurunkan prosentase ketidaklengkapan pengisian rekam medis yaitu dengan membentuk tim monitoring dan melakukan evaluasi secara berkala setiap satu kali dalam satu bulan untuk mengetahui besarnya prosentase ketidaklengkapan rekam medis serta menentukan solusi pemecahan masalah. Hal lain yang perlu diperbaiki adalah alur berkas rekam medis rawat inap agar bisa disesuaikan dengan standar pedoman penyelenggaraan rekam medis yang ada.

2. Indar I, Indar, dan Naiem MF. Faktoryang Berhubungan dengan Kelengkapan Rekam Medis di RSUD $H$. Padjonga DG. Ngalle Takalar. Jurnal Adminsitrasi \& Kebijakan Kesehatan Indonesia. 2013; 2(2): 10-18.

3. Mawarni D dan Wulandari RD. Identifikasi 
Ketidaklengkapan Rekam Medis Pasien Rawat Inap Rumah Sakit Muhammadiyah Lamongan. Identification of The Fulfilment of Medical Record Incompleteness in The Inpatient of Muhammadiyah Hospital Lamongan. Jurnal Administrasi Kesehatan. 2013; 1(2): 192-199.

4. Kurniawati D dan Sugiarti I. Tinjauan Pengisian Resume Keluar Rawat Inap Ruang Teratai Triwulan IV di RSUD Kabupaten Ciamis Tahun 2012. Jurnal Manajemen Informasi Kesehatan Indonesia. 2014;2(1): 26-31.

5. Pamungkas F, Hariyanto T, dan Utami EW. Identifikasi Ketidaklengkapan Dokumen Rekam Medis Rawat Inap di RSUD Ngudi Waluyo Wlingi. Jurnal Kedokteran Brawijaya. 2015;28(2): 124-128.

6. Ridho KM, Rosa EM, dan Suparniati E. Analisis FaktorFaktor yang Mempengaruhi Kepatuhan Pengisian Rekam Medis di Rumah Sakit Gigi dan Mulut Pendidikan UMY. Jurnal Medicoeticoilegal dan Manajemen Rumah Sakit. 2013; 2(2): 1-18.

7. Eny Y dan Rachmani E. Hubungan Pengetahuan Dokter dengan Kelengkapan Dokumen Rekam Medis Rawat Jalan di Poliklinik Neurologi RSUP Dr. Kariadi Semarang Oktober 2008. Jurnal Visikes. 2008; 9(1): 49-57.

8. Simbolon SA. Kajian Yuridis terhadap Kedudukan Rekam Medis Elektronik dalam Pembuktian Perkara Pidana Malpraktek oleh Dokter. Jurnal Lex Crimen. 2015;4(6): 152-161.

9. Lihawa C, Mansur M, dan Sarwiyata TW. FaktorFaktor Penyebab Ketidaklengkapan Pengisian Rekam Medis Dokter di Ruang Rawat Inap RSI Unisma Malang. Jurnal Kedokteran Brawijaya. 2015; 28(2): 119-123.

10. Pratiguna AA. Pengaruh Pre Akreditasi JCl (Joint Commission International) terhadap Kelengkapan
Data Rekam Medis Resume Pasien Rawat Inap di Rumah Sakit Dr. Moewardi Surakarta. Jurnal Infokes Apikes Citra Medika Surakarta. 2012; 2(2): 63-76.

11. Departemen Kesehatan Republik Indonesia. Pedoman Penyelenggaraan dan Prosedur Rekam Medis Rumah Sakit di Indonesia. Jakarta: Direktorat Jenderal Bina Pelayanan Medis; 2006.

12. Rahmadhani IS, Sugiarsi S, dan Pujihastuti A. Faktor Penyebab Ketidaklengkapan Dokumen Rekam Medis Pasien Rawat Inap Dalam Batas Waktu Pelengkapan di Rumah Sakit Umum Daerah Dr. Moewardi Surakarta. Jurnal Kesehatan. 2008;2(2): 82-88.

13. Rohman H, Hariyono W, and Rosyidah. Kebijakan Pengisian Diagnosis Utama dan Keakuratan Kode Diagnosis pada Rekam Medis di Rumah Sakit PKU Muhammadiyah Yogyakarta. Jurnal Kesehatan Masyarakat (Journal Of Public Health). 2011; 5(2): 162-232.

14. Solikhah, Pamungkas TW, dan Marwati T. Analisis Ketidaklengkapan Pengisian Berkas Rekam Medis di Rumah Sakit PKU Muhammadiyah Yogyakarta. Jurnal Kesehatan Masyarakat (Journal of Public Health). 2010; 4(1): 17-28.

15. Pratiwi AH, Hariyanti T, dan Susilo S. Pengembangan Alur Pasien dan Berkas Rekam Medis Sebagai Optimalisasi Sistem Informasi Rekam Medis. Jurnal Kedokteran Brawijaya. 2015; 28(2): 129-135.

16. Sari DP. Analisis Karakteristik Individu dan Motivasi Ekstrinsik terhadap Kinerja Dokter dalam Kelengkapan Pengisian Rekam Medis Pasien Rawat Jalan di Rumah Sakit Hermina Depok. [Tesis]. Universitas Indonesia, Depok. 2011.

17. Wuryandari G. Peningkatan Kelengkapan Rekam Medis. Jurnal Administrasi Kebijakan Kesehatan. 2013; 11(2): 60-65. 


\section{Lampiran 1}

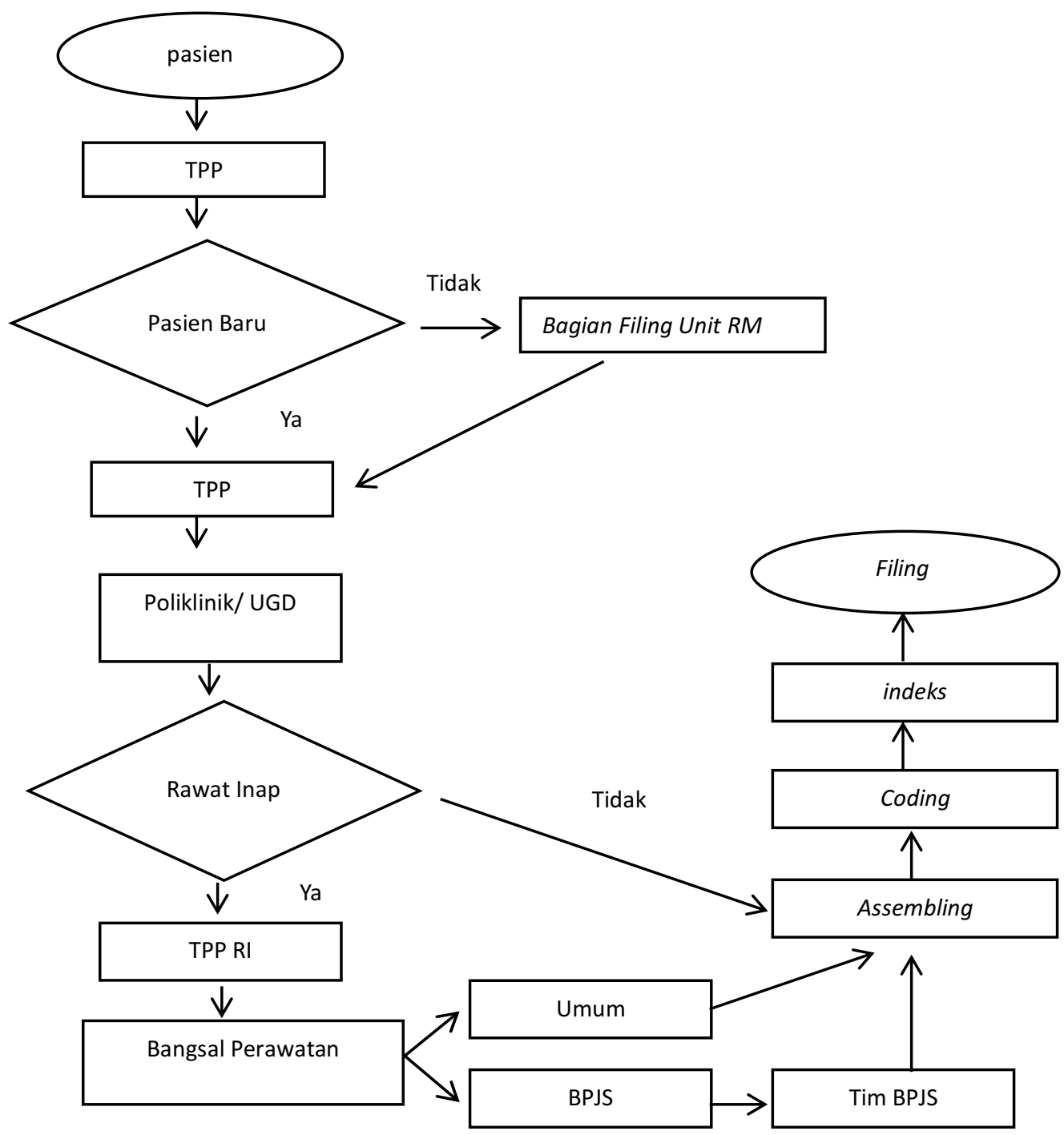

\footnotetext{
Alur Berkas Rekam Medis RS UMM

Keterangan:

TPP : Tempat Pendaftaran Pasien

TPP RI : : Tempat Pendaftaran Pasien Rawat Inap
} 


\section{Lampiran 2}

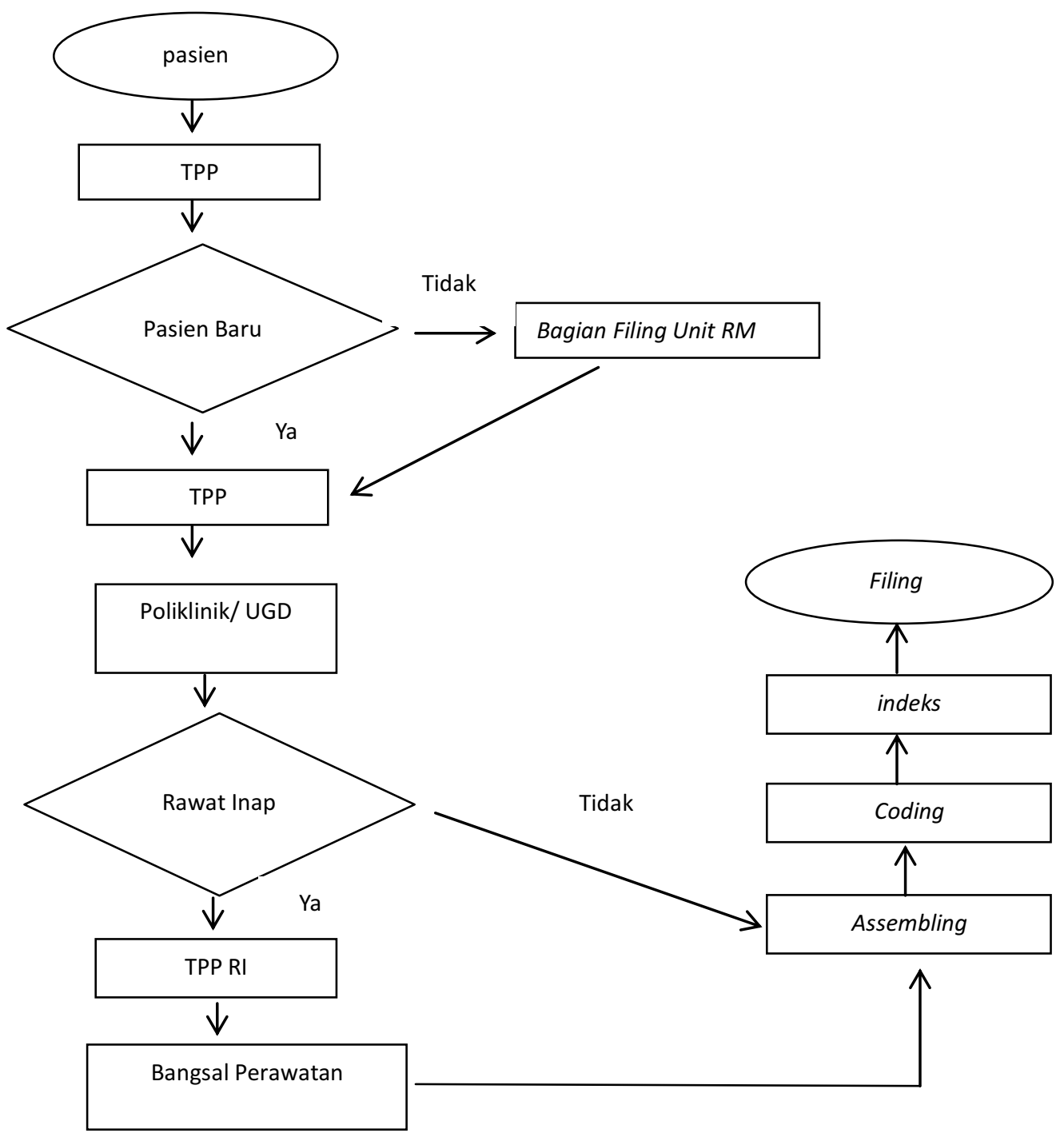

Alur Berkas Rekam Medis Rekomendasi

(Sumber : Pedoman Penyelenggaraan Rekam Medis DEPKES RI Tahun 2006) (11) Keterangan:

TPP : Tempat Pendaftaran Pasien

TPP RI : Tempat Pendaftaran Pasien Rawat Inap 